\title{
The Impact of Firm's Green Practices on the Sustainability in Supply Chain for Competitive Advantage: A Conceptual Framework
}

Nurasifa Norddin, Mohd Rizaimy Shaharudin, Jamaludin Akbar, Siti Fairuza Hassam, Shaiful Annuar Khalid

To Link this Article: http://dx.doi.org/10.6007/IJARBSS/v11-i10/11040

DOI:10.6007/IJARBSS/v11-i10/11040

Received: 07 August 2021, Revised: 09 September 2021, Accepted: 27 September 2021

Published Online: 14 October 2021

In-Text Citation: (Norddin et al., 2021)

To Cite this Article: Norddin, N., Shaharudin, M. R., Akbar, J., Hassam, S. F., \& Khalid, S. A. (2021). The Impact of Firm's Green Practices on the Sustainability in Supply Chain for Competitive Advantage: A Conceptual Framework. International Journal of Academic Research in Business and Social Sciences, 11(10), 621-637.

\section{Copyright: (c) 2021 The Author(s)}

Published by Human Resource Management Academic Research Society (www.hrmars.com)

This article is published under the Creative Commons Attribution (CC BY 4.0) license. Anyone may reproduce, distribute, translate and create derivative works of this article (for both commercial and non-commercial purposes), subject to full attribution to the original publication and authors. The full terms of this license may be seen at: http://creativecommons.org/licences/by/4.0/legalcode

$$
\text { Vol. 11, No. 10, 2021, Pg. } 621 \text { - } 637
$$

Full Terms \& Conditions of access and use can be found at http://hrmars.com/index.php/pages/detail/publication-ethics 


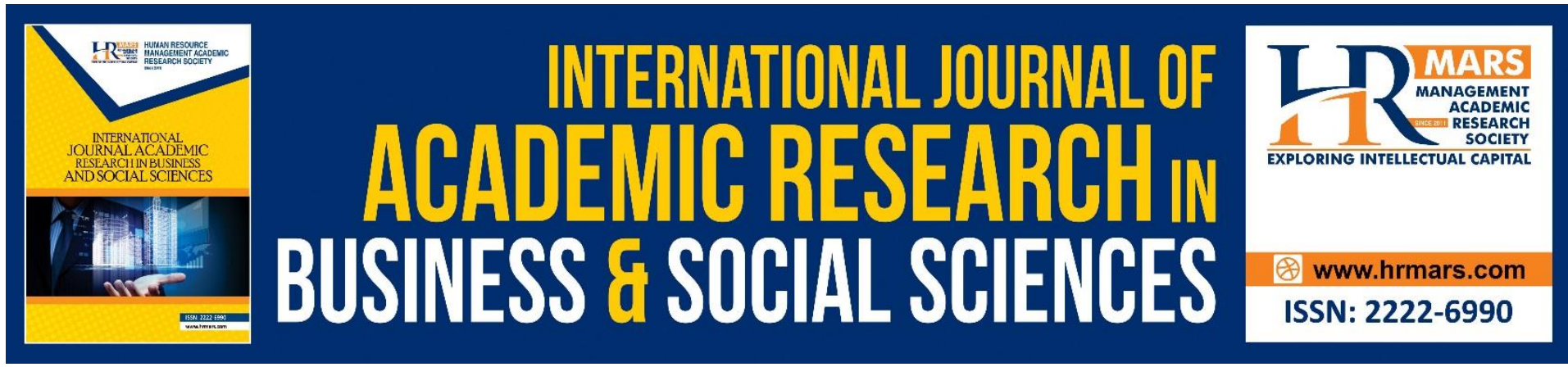

\title{
The Impact of Firm's Green Practices on the Sustainability in Supply Chain for Competitive Advantage: A Conceptual Framework
}

\author{
Nurasifa Norddin ${ }^{1}$, Mohd Rizaimy Shaharudin ${ }^{2}$ (Corresponding \\ Author), Jamaludin Akbar ${ }^{3}$, Siti Fairuza Hassam ${ }^{4}$, Shaiful \\ Annuar Khalid ${ }^{5}$ \\ 1,3,4 Faculty of Business Management, Universiti Teknologi MARA, Kedah, Malaysia, ${ }^{2}$ Smart \\ Manufacturing Research Institute (SMRI) Kompleks Kejuruteraan Sultan Abdul Halim Syah, \\ Fakulti Kejuruteraan Mekanikal, Universiti Teknologi MARA, Shah Alam, Selangor, Malaysia \\ ${ }^{5}$ Faculty of Business Management, Universiti Teknologi MARA, Perlis, Malaysia.
}

\begin{abstract}
This study aims to develop an enhanced model of green practices for the company's sustainability in achieving competitive advantage. The study used the conceptual development framework used two data sources: journal publication (secondary data) and field interview (primary data). The finding of the secondary data revealed ten green practices from the literature review; remanufacturing, eco-design, process design, lean practices, cleaner production, product design, product return practices, product recovery practices, green purchasing, and reverse logistics. However, based on the interviews with the three selected companies in the electrical and electronics industry, it was discovered that only four green practices were the actual practices adopted by the companies: lean practices, product return practices, product recovery practices, and green purchasing. A grounded theory of Natural Resources-based View (NRBV) The model predicted the relationship between green practices and sustainability, green practices and competitive advantage, and the relationship between sustainability in the supply chain and competitive advantage. Therefore, it is anticipated that manufacturing firms with higher green practices adoption can increase sustainability in the supply chain, which eventually attains high competitiveness in the market.
\end{abstract}

Keywords: Green Practices, Sustainability, Supply Chain, Competitive Advantage

\section{Introduction}

Environmental barriers are declining due to the development of new tools, which increase the ability to communicate, share information and deliver things efficiently and more effectively (White, 2019). Thus, these reasons provided opportunities for certain firms to gain a competitive advantage over their competitors worldwide. In addition, the new competitive environment is more global, focuses on technology and customers, reduces product life cycles, accelerates market and customer demand, accelerates feedback and delivers high- 
quality products and services to customers (Thatte et al., 2013). Kamukama et al (2011) also suggested that sustainability would impact the competitive advantage of the company's financial position. Moreover, the slowdown in adopting green practices in the E\&E industry in Malaysia has led to a lack of competitive advantage in exporting manufacturing (Iranmanesh et al., 2015). Therefore, this study seeks to reduce the gap by studying the relationship between green practices and sustainability, the relationship between green practices and competitive advantage, and the relationship between sustainability in the supply chain and competitive advantage.

In relation to this, Menguc and Ozanne (2005) found that sustainability in social sustainability leads to improved competitiveness. However, the literature on manufacturing and performance strategies failed to highlight sustainability in the supply chain as a key element in achieving a competitive advantage. This is demonstrated by the lack of attention paid to sustainability in recent publications, highlighting quality, delivery, flexibility, innovation and cost as an ambitious production objective (Shahbazpour \& Seidel, 2006). Also, this study can help manufacturers in identifying the best green practices that influence the company's sustainability in the supply chain and ultimately achieve competitiveness in the marketplace. The policies and strategies being developed under the $12^{\text {th }}$ Plan are to improve the electrical and electronic industry's competitiveness and environmental sustainability, in line with Malaysia's vision of Shared Prosperity Vision 2030, which aims to boost the country's economic growth and close the economic divide in society. To achieve sustainability in an organization and a competitive advantage, the organization needs to have a stronger relationship in economic, environmental and social aspects. Hence, the study must determine the relationship between green practices, the sustainability in supply chain and competitive advantage. This study also aligns with government aspirations to achieve Sustainable Development Goals (SDGs) by 2030, under SDG goal number 12, responsible consumption and production.

\section{Literature Review}

In this study, the variable described as dependent on competitive advantages, the independent variable consists of green practices (lean practices, product return practices, product recovery practices, green purchasing), and the mediating variable consists of sustainability in the supply chain, as well as the relationship between the variables.

\section{Competitive Advantage}

Competitiveness refers to a company's ability to outperform its competitors in terms of supplying goods and services efficiently and effectively in response to market needs (Tan et al., 2019). Competitive advantage can be achieved if the company's practices can enhance brand reputation, reduce energy consumption, reduce costs and minimize waste, resulting in improved long-term economic performance (Ali et al., 2019). Furthermore, existing empirical green practises in supply chain management research literature broadly agree with Rao and Holt (2005) on the importance of using the three key price or delivery, quality, cost and measures as competitive measures. In addition, firms implementing sustainability in the supply chain tend to benefit economically from some operational cost savings, such as a reduction in environmental compliance costs (Choi et al., 2016).Other than that, the competitive advantage may increase the profitability resulting from higher revenues and lower costs resulting from cost or competitive differentiation strategies (Cantele \& Zardini, 
2018). Green practices in the supply chain can lead to tangible benefits such as improved quality and reduced profit and competitive advantage (Younis et al., 2016).

\section{Green Practices}

Green practises are becoming increasingly important for an organization as they lead to supply chain sustainability and, ultimately, a competitive advantage in the marketplace (Zailani et al., 2012). In addition, Scur and Barbosa (2017) indicated that manufacturers generally adopt green practices and have high environmental and social performance, including proper compliance with environmental regulations. At the same time, companies are adopting green practices to compete and increase sales, by increasing their market share (Yildiz \& Sezen, 2018). Green practices have an impact on the sustainability performance of the company in terms of profitability and ultimately to achieve a competitive advantage in the marketplace, including a reduction in price or cost, an increase in quality and delivery as well as a reduction in waste disposal (Yildiz \& Sezen, 2018). Green practices have been identified in the middle of the supply chain, involving waste management, selecting suppliers with environmental credibility, producing more green products to reduce pollution during operation, educating downstream suppliers to enhance environmental performance, and collaborating with suppliers in their firms (Shaharudin et al., 2016). The benefits of cost management, which drive profitability, are key factors that encourage firms to adopt green practices and have an impact on market competitiveness (Shaharudin et al., 2016).

\section{Lean Practices}

Continuous improvement is related to lean practice and requires full support from the management (Zailani et al., 2015). By implementing lean practices throughout the supply chain improves economic, environmental, and social performance (Cherrafi et al., 2018). Green practises were previously described as a multidimensional construct in a previous study. The benefits of integrating lean practices include reduced lead time and costs, improved process flow, better relationships with suppliers, customers, and other stakeholders, improved environmental quality as well as employee morale and commitment (Cherrafi et al., 2018). In addition, lean practices need to pay attention to both performance improvement and capacity development (Gupta et al., 2015). Lean and sustainable production has a significant impact on multiple operational performance measures when implemented simultaneously rather than separate functions (Gupta et al., 2015). Moreover, lean manufacturing practices are one of the practices that impact environmental factors such as waste reduction, energy, and resource management on sustainability performance (Ali et al., 2019). Lean production involves just in time, total quality management, and employee involvement, which emphasises price or cost, quality, and delivery time, with the assessment of every activity carried out in productions (Das, 2017).

\section{Product Return Practices}

Product returns, for example, are a type of waste that is redirected back to the supply chain system for further recovery operations via various reuse or recycling processes (Shaharudin et al., 2017). Product return practices shall include the prevention, receipt, and processing of the product used or damaged from the point of origin to remanufacture and reuse (Huang et al., 2016). The previous study found that legislation and regulations are the most important driver of product return practices, as seen from the increasing number of directives, regulations, and obligations adopted in several countries around the world, covering many 
products such as batteries, end-of-life vehicles, packaging, electrical and electronic equipment, and others (Zailani et al., 2017).

In addition, Mollenkopf et al (2011) highlighted those regulatory changes in the retail market such as electrical and electronic equipment (WEE) and hazardous materials (RoHS) restrictions have increased the implementation of the product return practices. Rahman and Subramanian (2012) identified government regulation as one of the key drivers influencing the implementation of end-of-life recycling operations. In addition, through developed and developing countries such as Japan, Korea, Taiwan, and China, legislation on manufacturer liability has been introduced to make manufacturers responsible for collecting and recycling the used products (Lee \& Na, 2010; Toffel et al., 2008). However, product returns governance in Malaysia is still a legal concept without a framework for implementation, with only a few multinational companies operating in Malaysia receiving equipment through a major return policy, namely Motorola, Nokia, Dell, HP, and Apple (Agamuthu \& Victor, 2011).

\section{Product Recovery Practices}

Product recovery operations are widely recognized as environmental practices for endproduct processing that helps the product returns, components and materials process (Gupta et al., 2015). Product recovery management is defined as the management of all used and discarded products, components, and materials used and disposed of by a manufacturing company legally and responsibly (Um \& Suh, 2015). It refers to the recovery of the value of the products used or damaged by repair, recovery, remanufacturing, and recycling (Huang et al., 2016). Product recovery is a relatively new domain from the corporate system perspective (Madaan et al., 2015).

In addition, the recovery of products is mainly due to three hidden reasons which are the value of economic waste, market requirements, and government regulation. Material recovery typically involves the disassembly of materials and the processing of materials, such as chemical operations required for the product used. The main objective is to minimise the volume of disposal and to maximise the volume of material returned to the production cycle (Gupta et al., 2015). Other than that, 6R such as reduce, reuse, recycle, recover, remanufacture, redesign are proactive practices that primarily focus on the product improvement, process, and system across the supply chain.

\section{Green Purchasing}

Green purchasing is described as enhancing the environmental aspects of price and performance criteria when making purchasing decisions with the primary purpose of reducing the environmental impact on resources efficiency (Ramakrishnan, Haron, \& Goh, 2015). The study has conceptualized green practices as lean practices, product return practices, product recovery practices and green purchasing. Organisations that want to adopt green purchasing practices should take the opportunity to evaluate their business processes through the supply chain (Ramakrishnan et al., 2015).

Moreover, the purpose of purchasing is the first step in the value chain where its success depends on the incorporation of environmental strength, purchasing activities, and the objective of the environment (Carter et al., 2000). Green purchasing activities are also an essential component of green supply chain management (Yildiz \& Sezen, 2019). The awareness of environmental problems has catalysed environmental degradation efforts 
through green purchasing practices (Ramakrishnan et al., 2015). Thus, green purchasing is an environmental purchase comprising of involvement in activities that include reduction, reuse, recycling of materials in the purchasing process (Ramakrishnan et al., 2015).

\section{Remanufacturing}

Remanufacturing is a product recovery option that improves the quality of returns to goods with new circumstances. Re-manufacture product costs are low and are sold with the same or better warranty for new products (Mitra, 2015). In addition, Mitra (2015) also argues that recycling can also lead to increased profits, reduce the use of resources and energy as well as reduce the negative effect on the environment. Other than that, various products that can be re-manufactured includes electronic products, cartridge, and mobile phones (Bulmuş et al., 2014). Remanufacturing is also a practice that reduces costs, reduces harm to the environment as it reduced the use of raw materials. Remanufacturing is also the process of recovering a product used for a new circumstance by repair, reuse, refurbished, and replacing a certain part, as well as guaranteeing warranties as possible for a new product (Chen \& Ulya, 2019).

\section{Eco Design}

Eco-design can be defined as environmental-conscious design and design that concerns the environment. It refers to actions taken during product development which is to minimise impact environmental from manufacturing, use, and disposal (Eltayeb \& Zailani, 2009). Besides that, Dangelico and Pontrandolfo (2010) had mentioned that eco-design integrates environmental features into products to minimise risks of emissions distributed during production, consumption, and disposal stages of the product life cycle. Eltayeb and Zailani (2010) mentioned that eco-design activities in Malaysia such as designing for reuse, remanufacturing, and recycling are feasible studies. Other than that, the benefits of ecodesign can be realised when returns are reprocessed for reuse of materials, in the form of sub-assemblies or whole products (Khor \& Udin, 2013).

\section{Process Design}

Manufacturing companies need process design for products moving without hazardous waste (Gupta et al., 2015). Furthermore, process design is important to take out all components which each of the components will be classified into groups by experts from different manufacturers. These practices should be done strictly to maintain high quality which is still enclosed by the parts which are group go to the reuse, re-manufacture, or recycle processes. A good quality component will be directly reused for a new product. Some of them need remanufacturing and the rest will continue to be the recycling process (Arthaya \& Nathania, 2017). Besides that, successful process design suitability of the process to overall organisation objective, which requires a view of the whole organisation should not have a biased viewpoint and the process should deliver value with constant involvement of the management at various stages (Jacobs \& Chase, 2017).

\section{Cleaner Production}

Cleaner production is designed to show that the prevention or reduction of wastes and emissions at source can improve the environmental, as well as economic performance of the participating organisation (Gupta et al., 2015). Implementation of successful cleaner production can encourage efficient facilities, reduction of disposal technology, value-added materials, energy efficiency, and quality system (Gupta et al., 2015). Cleaner production is 
therefore linked to the continuous implementation of an integrated preventive environmental strategy applied to processes, products, and services to increase overall efficiency and reduce risks to humans and the environment. Cleaner production can be applied to the processes used in any industry, to the products themselves, and the various services provided by society (Yan et al., 2016). Cleaner production prevents pollution at the source and the manufacturing process, rather than removing it after it has been created (Hami et al., 2016). Efficient use of resources and green materials is needed to facilitate cleaner production, making it a matter of urgency, particularly in the high-tech industrial value chains (Yan et al., 2016).

\section{Product Design}

A study by Khor and Udin (2013) revealed that product design is a knowledge resource such as the development of talents, creativity, or practical skills to meet the needs of the current market and ultimately achieve a competitive edge. The goals of green product design are to minimise resources and reduce the capacity for toxic emissions (Khor \& Udin, 2013). Besides that, product design is a key to reduce return costs from production to demand products (Ülkü \& Hsuan, 2016). Besides that, product design also makes cost savings during production because of the reduced cost of assembly, making it easier to achieve performance in economies scale ( $\mathrm{Wu}, 2012)$. In addition, the design of the product should be based on environmentally friendly raw materials, parts, and components. If the products need to be disposed of and recycled, they should contain more biodegradable and recyclable materials (Mitra \& Datta, 2014). Hence, product design positively impacts environmental sustainability and could ultimately bring competitiveness and economic performance to the firm (Mitra \& Datta, 2014).

\section{Reverse Logistics}

Reverse logistics is defined as an efficient process for the planning, execution, and handling of raw materials, processing costs, process inventory, finished goods, and related information from point of use to point of origin for recovery of value or disposal (Khor \& Udin, 2013). In addition, reverse logistics is one of the most common green practices in the management of existing supply chains. It involves the green process of planning, implementing, and controlling the cost-effective flow of materials used, used goods, and related information from point of use to point of origin for proper disposal (Arthaya \& Nathania, 2017). Furthermore, reverse logistics is linked to investment recovery in past green supply chain literature. It refers to traditional business practices where excess inventory and materials or used materials are resold and become one of the most investigated dimensions of green practice in supply chain management studies (Yildiz \& Sezen, 2019). The objective of the investment recovery is to recover the highest value from obsolete products, end-of-life, and surplus goods and then, concisely, to recover assets, to try to include these items in the reverse logistics process (Yildiz \& Sezen, 2019).

\section{Sustainability in Supply Chain}

Sustainability is the supply chain management that plays an essential role to improve the organization's overall performance and obtaining a competitive advantage (Tan, Zailani, Tan, $\&$ Yeo, 2019). Sustainability also refers to the company's economic, social and environmental performance in achieving market competitiveness (Ali et al., 2019). Besides that, according to Shaharudin et al. (2014), sustainable supply chain management is a set of policies on supply 
chain management, actions taken, and relationships designed to respond to natural environmental concerns concerning the design, distribution, use, reuse, and disposal of the goods and services of the company. Moreover, to achieve sustainable performance usually, firms focus on wealth creation through greater economic performance in terms of assets, liabilities, and overall market strength (Chin et al., 2015). As a developing country, Malaysia is increasingly focusing on economic development and, at the same time, continuing progress in environmental and social protection. This pressure has created challenges for companies to maintain economic, environmental, and social performance (Zailani et al., 2015). To achieve a sustainable competitive advantage, the sustainability performance of a company requires a high link between economic, environmental, and social performance (Thoo et al., 2013).

Economic performance refers to the elements such as cost reduction and productivity, market share, and profitability (Ali et al., 2019). Besides that, the economic performance is also the most essential effort for the firms especially in developing countries, adopting eco-friendly practices that eventually impact competitive advantages (Ali et al., 2019). Firms with higher levels of green practices on the sustainability in the supply chain tend to gain economic benefits in terms of some operating cost savings such as lowering environmental agreement costs, but also exposed to higher operating costs such as rising costs to buy eco-friendly materials (Choi et al., 2016).

Environmental performance is also defined as corporate activity on the impact of environmental performance and as the point at which environmental activities are undertaken by the company to reduce the environmental impact (Tan et al., 2019). Environmental sustainability performance refers to the reduction in the use of hazardous substances, the generation of waste, energy use, and use of materials, as well as compliance with environmental regulations (Ali et al., 2019). In addition, the growing concern and awareness among the public about eco-friendly business processes, which can lead companies to show extraordinary commitment to green practices such as recycling, reuse, and materials reduction (Chin et al., 2015).

Sustainability is a business strategy that is closely related to corporate social responsibility. Specifically, the organisation, environment, and society are the triads that are mutually dependent for a shared value or a win-win solution (Chin et al., 2015). Specifically, firms that react actively towards social values can achieve a social image and social legitimacy for their long-term survival and competitiveness (Hoffman, 2000). Furthermore, social performance refers to the ability of the firm to meet or exceed stakeholder expectations regarding social issues and consequently to enhance the firm's image in the eyes of the public and employees (Ali et al., 2019). Hence, to achieve a long-lasting competitive advantage, organisational sustainability requires a high intersection of economic, environmental, and society (Thoo et al., 2013).

\section{Natural Resources-based View Theory (NRBV)}

As environmental competitiveness becomes increasingly essential in business, the natural resource-based view (NRBV), which evolved from its original theory, is well suited in explaining the study's research framework (Tan et al., 2019). The NRBV adds a natural environment (external environment) as a valuable source of firms that will make firms 
competitive. The natural resource-based view (NRBV) explains that combining resources internally and externally in the supply chain creates a better organizational ability to meet customer expectations (Tan et al., 2019). The input is represented by the green practices, followed by the sustainability in the supply chain and the competitive advantage exemplifies the outcome (output). The green practices significantly influence on the supply chain sustainability for competitive advantage that is grounded by the (NRBV) theory. According to this theory, firms will be unique in adopting sustainability in the supply chain and achieving competitive advantages by exploiting internal resource (such as lean practices, product return practices, product recovery practices, and green purchasing). This also signified that competitive advantage could be achieved when sustainability in the supply chain and green practices are adopted.

\section{Methodology}

Research Design

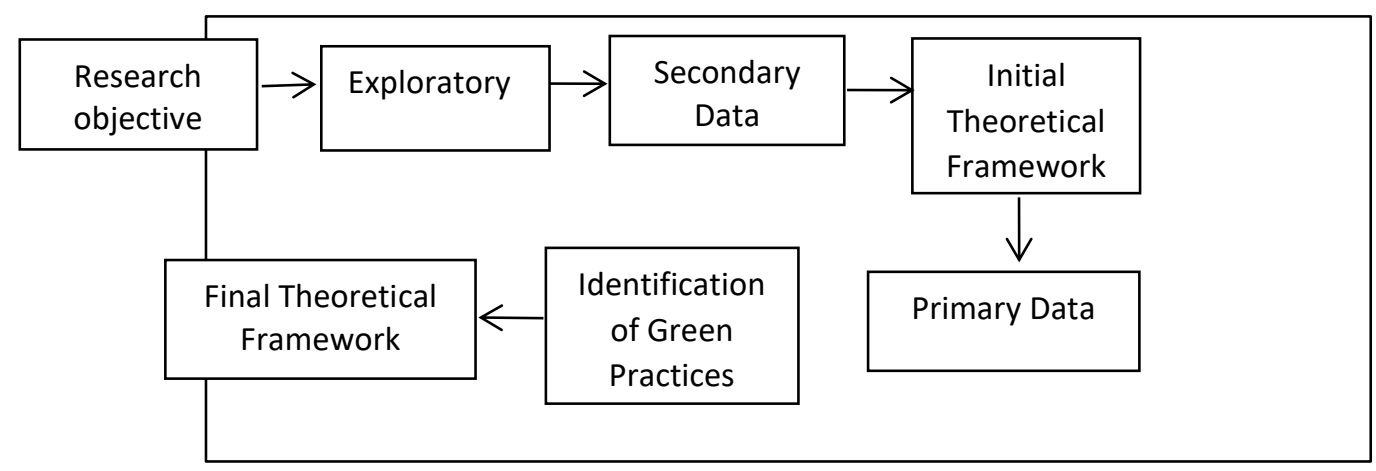

Figure 3.1: Research Design

The study uses two data sources, journal publication (secondary data) and field interview (primary data). The first step was identifying the relevant green practices before the conceptual development framework. A literature review that focused on the green or environmental supply chain areas has been conducted to determine the latent construct and the possible gaps for this study. This is used to initiate the foundation of the framework of the green practice. The quantitative content analysis (secondary data) from the literature study served as the foundation for the field interview (primary data).

\section{Interview Methodology}

The data were retrieved from the semi-structured interviews that were conducted to the three selected companies. In this context, and the sampling method is used in selecting the three companies. Sekaran (2013) pointed out that this method refers to sampling specific types of respondents that the researcher seeks based on their expertise and control information. Therefore, only E\&E manufacturing firms with EMS ISO 14001 certified firms in Malaysia were selected in this study. Moreover, the study relates to the green practices initiative, which leads to sustainable performance, achieve profitability, and eventually achieve market competitiveness. The study, therefore, tried to obtain information from the respective employees of companies engaged in the green practices.

Regarding the basic reason for using the variables, it is vital to confirm the practices that the variables may reflect on the real situation in Malaysia, which country will carry out this 
research. Within four months, the researcher approached twenty companies via various modes of communication, such as phone calls and e-mails. This includes a request for participation made to respondents indirectly through the researcher's friends who work in the industry. However, due to the busy and heavy workload, not everyone agrees to participate, and some remain silent without responding to the request. Only three companies can participate in the interviews after a follow-up and an arrangement for interviews during office hours or outside business hours. The eligible companies were labelled as Company $A$, $B$, and $C$, as the companies are from the electrical and electronic industries.

To get clear information about the adoption of the green practice in each company, the interview began with Senior Manager in Company A who is certified in the environmental management system (EMS) ISO 14001 and certified with quality management ISO 900:2015. This is followed by a second interview with a Logistic and Supply Chain Manager of Company $B$ in which the company is focused on delivering best in class electronic manufacturing, product development, and supply chain solution to OEM in the industry and has certified ISO 14001 company, OHSAS 18001 as well as members of IECC (Electronic Industry Citizen Coalition) and SEDEX (Supplier Ethical Data Exchange). The third interview was conducted with a Senior Manager Lean Expert of Company $C$ which is focused on life science products or medical devices and has a certified Quality Management System for Medical Devices (ISO 13485). Table 2.1 provides the summary of the background information about the three participating companies in the interview for the development of the research framework.

A brief explanation of the interview objective was provided to the company through telephone calls and direct verbal communication with the interviews. Concerning the adoption of green practices, they interviews carried out with all the three responded companies, as they were fully aware of the interview objective and of the expected questions to be answered. During the interview session, the researcher asked questions from a list of questions that had been prepared before the interview. Table 1 indicates key profile for all companies participating in the interview. 


\begin{tabular}{|c|c|c|c|}
\hline Items & Company A & Company B & Company C \\
\hline $\begin{array}{l}\text { Year } \\
\text { Established }\end{array}$ & 1995 & 1993 & 1999 \\
\hline $\begin{array}{l}\text { Number of } \\
\text { Employees }\end{array}$ & 1,500 & 3,000 & 13,500 \\
\hline Business Type & Semiconductors & Electronic & Automated \\
\hline Annual Sales & RM27.1 billion & RM1.2 billion & RM2.5 billion \\
\hline Products & $\begin{array}{l}\text { CMOS logic, high- } \\
\text { voltage, mixed- } \\
\text { signal, } \\
\text { radiofrequency, } \\
\text { and micro- } \\
\text { electro- } \\
\text { mechanical- } \\
\text { system } \\
\text { technologiesICs, } \\
\text { Power } \\
\text { electronics, ESD } \\
\text { Protection Diodes }\end{array}$ & $\begin{array}{l}\text { Medical devices, } \\
\text { lighting, HVAC, } \\
\text { computing, } \\
\text { medical devices, } \\
\text { lighting and } \\
\text { mobile } \\
\text { communications. }\end{array}$ & $\begin{array}{c}\text { Medical } \\
\text { instrument } \\
\text { devices, } \\
\text { analytical } \\
\text { instrument \& } \\
\text { supplies, life } \\
\text { science, } \\
\text { clinical \& } \\
\text { diagnostic } \\
\text { testing } \\
\text { vacuum and } \\
\text { leak } \\
\text { detection, lab } \\
\text { automation }\end{array}$ \\
\hline $\begin{array}{l}\text { Quality } \\
\text { Standards }\end{array}$ & $\begin{array}{c}\text { IATF 16949:2016, } \\
\text { ISO 9001:2015, } \\
\text { IECQ QC 080000, } \\
\text { OHSAS } \\
\text { 18001:2007, ISO } \\
\text { 14001:2015 } \\
\text { NATIONAL FIRE } \\
\text { and ISO/IEC } \\
27001: 2013\end{array}$ & $\begin{array}{c}\text { ISO 13485:2016, } \\
\text { ISO 14001:2015, } \\
\text { ISO 9001:2015, } \\
\text { MD 1722:2011, } \\
\text { OHSAS } \\
\text { 18001:2007 }\end{array}$ & $\begin{array}{c}\text { ISO } 9001: \\
2015 \\
\text { MDA 2012: } \\
\text { ISO } \\
\text { 14001:2015 } \\
\text { ISO } \\
\text { 13485:2016 }\end{array}$ \\
\hline
\end{tabular}

Table 1: Key Profile for All Companies Participating in the Interview 
Table 2: Excerpt/Extract of Green Practices

\begin{tabular}{|c|c|c|c|c|c|c|c|c|c|c|c|}
\hline \multirow[t]{2}{*}{ No } & \multirow[t]{2}{*}{ Company } & \multicolumn{10}{|c|}{ Open Code } \\
\hline & & $\mathbf{R}$ & ED & PD & LP & $\mathrm{CP}$ & $\begin{array}{c}\text { PR } \\
\text { D }\end{array}$ & $\begin{array}{l}\mathbf{P} \\
\mathbf{R}\end{array}$ & RC & GP & $\mathbf{R L}$ \\
\hline 1 & $\begin{array}{l}\text { Company } \\
\text { A }\end{array}$ & $\mathrm{V}$ & & & $\mathrm{V}$ & $\sqrt{ }$ & $\mathrm{V}$ & $\mathrm{v}$ & & $\sqrt{ }$ & \\
\hline 2 & $\begin{array}{l}\text { Company } \\
\text { B }\end{array}$ & & $\mathrm{V}$ & & $\mathrm{V}$ & & & $\mathrm{V}$ & $\sqrt{ }$ & $\mathrm{V}$ & $\mathrm{V}$ \\
\hline 3 & $\begin{array}{l}\text { Company } \\
\text { C }\end{array}$ & & & & $\mathrm{V}$ & & & $\mathrm{V}$ & $\mathrm{V}$ & $\mathrm{V}$ & \\
\hline & $\begin{array}{l}\text { Percent } \\
\text { (\%) }\end{array}$ & 1 & 1 & 0 & 3 & 1 & 1 & 3 & 2 & 3 & 1 \\
\hline
\end{tabular}

Note: $\mathrm{R}=$ Remanufacturing, $\mathrm{ED}=\mathrm{Eco}$ Design, $\mathrm{PD}=$ Process Design, $\mathrm{LP}=$ Lean Practices, $\mathrm{CP}=$ Cleaner Production, $\mathrm{PRD}=$ Product Design, $\mathrm{PR}=$ Product Return, $\mathrm{RC}=$ Product Recovery, $\mathrm{GP}=$ Green Purchasing and RL $=$ Reverse Logistic.

A summary of the interview on adopting green practices by the companies are shown in Table 2 above. By convention, the following green practices consisted of the top four of the practices highlighted by the respondents and were considered appropriate to be chosen as study variables:

i. Lean Practices

ii. Product Return Practices

iii. Product Recovery Practices

iv. Green Purchasing

\section{Results}

The final model results are based on secondary and primary data, with the underpinned theory of Natural Resources-based View (NRBV) used to support the relationships. The finding for secondary data is the adoption of ten green practices identified from the literature review (remanufacturing, eco-design, process design, lean practices, cleaner production, product design, product return practices, product recovery practices, green purchasing, and reverse logistics). Next, the data analysis was gathered from in-depth interviews conducted through semi-structured interviews with three selected manufacturers in the Northern Region of Peninsular Malaysia.

Based on the interview with the three companies selected, not all companies completely practice all ten green practices. It was discovered that most companies are implementing several green practices, but none carry out all of the practices. By convention from the analysis, the following green practices were highlighted by the respondents in the top four practices. Therefore, they were deemed appropriate for the study variables: lean practices, product return practices, product recovery practices, and green purchasing as independent variables. Hence, the findings of this study are the conceptual framework which contained three elements, green practices as the independent variable, sustainability in the supply chain as the independent/intervening variable, and competitive advantage as the dependent variable. This study proposed that impact of green practices on the firm's significantly impact the sustainability in the supply chain for competitive advantage. In addition, sustainability in 
the supply chain influences the firm's competitive advantage. In other words, firms are expected to be in the best position to achieve profitability and, eventually, market competitiveness by implementing sustainable operating practices.

As such, the results of interviews and supported by the underpinning of NRBV theory, a realistic conceptual framework has been successfully developed. The conceptual framework illustrated in Figure 1 signified that four green practices, lean practices, product return practices, product recovery practices, and green purchasing practices, influenced sustainability in the supply chain and eventually impacted the firm's competitive advantage.

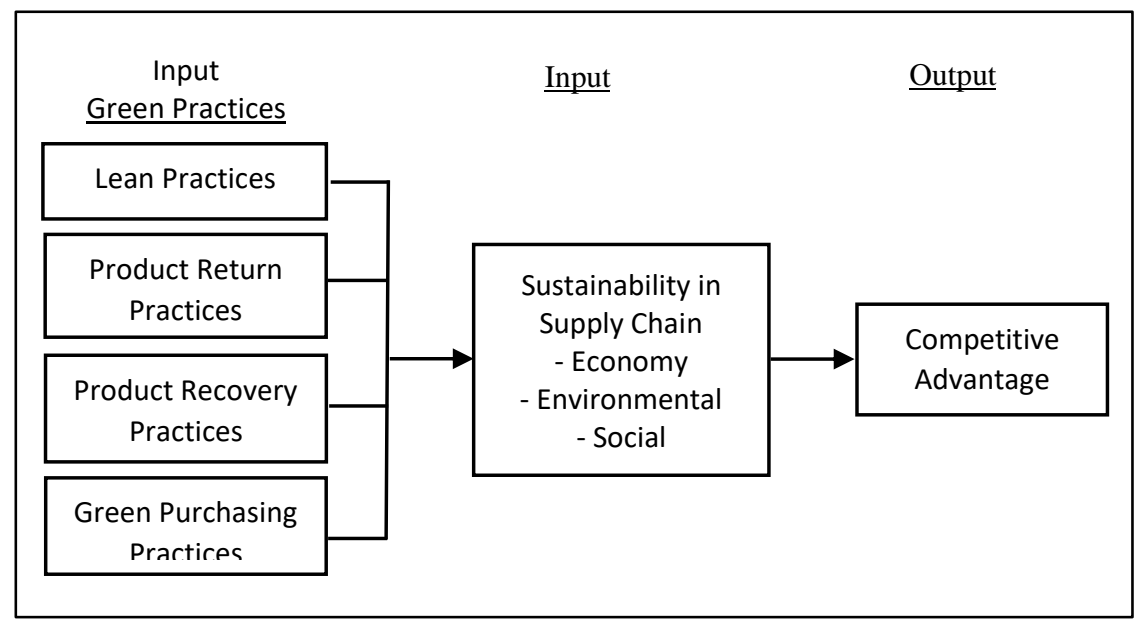

Figure 1: Conceptual Framework of the Study

\section{Conclusion}

The development of the enhanced model of green practices is vital by elucidating valuable information about the importance of green practices on the firm's sustainability in the supply chain for competitive advantage. From the interviews field, it is apparent that firms applying green practices will eventually achieve economic cost savings through waste reduction, energy usage optimization and less consumption of materials. Social and environmental sustainability are also prevalent in improving the firm's sustainability. By achieving the three bottom line, firms can significantly achieve the greatest performance and eventually achieve cost, quality and delivery competitiveness in the marketplace.

This research makes a practical contribution by promoting comprehensive strategic planning that will boost Malaysia's electrical and electronics industry's competitiveness and performance. Furthermore, green practises may assist manufacturing companies in identifying appropriate green practises to improve sustainability performance in practise. The Malaysian government's goal of achieving the Sustainable Development Goals (SDGs) by 2030 necessitates the adoption of applicable green measures. Furthermore, firms are believed to be in a wonderful position to gain profitability and eventually market competitiveness by using the principles in their operations.

This work makes a significant theoretical addition by offering a viable research model for the study of green practises, supply chain sustainability, and competitive advantage, particularly in Malaysia, where businesses are mostly unresponsive to environmental concerns (Albino, Balice \& Dangelico, 2009). Firms will be unique in embracing sustainability in the supply chain 
and generating competitive advantages by utilising internal resources through the lens of NRBV (such as lean practices, product return practices, product recovery practices, and green purchasing). Aside from that, in this study, green practises (such as lean practises, product return practises, product recovery practises, and green purchasing) and supply chain sustainability (economic, social, and environmental) can be considered resources that provide inputs to the firm's process, whereas competitive advantage represents the firm's outcome by delivering value from the adoption of green practises and supply chain sustainability.

\section{Acknowledgements}

This work is supported by Fundamental Research Grant Scheme (FRGS), by the Ministry of Education Malaysia (MOE) reference number FRGS/1/2018/SS01/UITM/03/05.

\section{References}

Ali, M. H., Zailani, S., Iranmanesh, M., \& Foroughi, B. (2019). Impacts of Environmental Factors on Waste, Energy, and Resource Management and Sustainable Performance. Sustainability, 11(8), 2443. https://doi.org/10.3390/su11082443

Agamuthu, P., \& Victor, D. (2011). Policy trends of extended producer responsibility in Malaysia. Waste Management and Research, 29(9), 945-953. https://doi.org/10.1177/0734242X11413332

Arthaya, B., \& Nathania, E. (2017). Alternative Scheme for Handling Reversely the Waste of Mobile Phone in Bandung, Indonesia. Insist, 2(1), 35. https://doi.org/10.23960/ins.v2i1.31

Albino, V., Balice, A., \& Dangelico, R. M. (2009). Environmental strategies and green product development: An overview on sustainability-driven companies. Business Strategy and the Environment, 18(2), 83-96. https://doi.org/10.1002/bse.638

Bulmuş, S. C., Zhu, S. X., \& Teunter, R. H. (2014). Optimal core acquisition and pricing strategies for hybrid manufacturing and remanufacturing systems. International Journal of Production Research, 52(22), 6627-6641. https://doi.org/10.1080/00207543.2014.906073

Cherrafi, A., Garza-Reyes, J. A., Kumar, V., Mishra, N., Ghobadian, A., \& Elfezazi, S. (2018). Lean, green practices and process innovation: A model for green supply chain performance. International Journal of Production Economics, 206, 79-92. https://doi.org/10.1016/j.ijpe.2018.09.031

Choi, S. B., Min, H., Joo, H. Y., \& Choi, H. B. (2016). Assessing the impact of green supply chain practices on firm performance in the Korean manufacturing industry. International Journal of Logistics Research and Applications, 20(2), 129-145. https://doi.org/10.1080/13675567.2016.1160041

Cantele, S., \& Zardini, A. (2018). Is sustainability a competitive advantage for small businesses? An empirical analysis of possible mediators in the sustainability-financial performance relationship. Journal of Cleaner Production, 182, 166-176. https://doi.org/10.1016/j.jclepro.2018.02.016

Carter, C. R., Kale, R., \& Grimm, C. M. (2000). Environmental purchasing and firm performance: An empirical investigation. Transportation Research Part E: Logistics and Transportation Review, 36(3), 219-228. https://doi.org/10.1016/S1366-5545(99)000344 
Chen, C. K., \& Ulya, M. A. (2019). Analyses of the reward-penalty mechanism in green closedloop supply chains with product remanufacturing. International Journal of Production Economics, 210, 211-223. https://doi.org/10.1016/j.ijpe.2019.01.006

Chin, T. A., Tat, H. H., \& Sulaiman, Z. (2015). Green supply chain management, environmental collaboration and sustainability performance. Procedia CIRP, 26, 695-699. https://doi.org/10.1016/j.procir.2014.07.035

Dangelico, R. M., \& Pontrandolfo, P. (2010). From green product definitions and classifications to the Green Option Matrix. Journal of Cleaner Production, 18(16-17), 1608-1628. https://doi.org/10.1016/j.jclepro.2010.07.007

Das, D. (2017). Development and validation of a scale for measuring Sustainable Supply Chain Management practices and performance. Journal of Cleaner Production, 164, 13441362. https://doi.org/10.1016/j.jclepro.2017.07.006

Eltayeb, T. K., \& Zailani, S. (2009). Going Green Through Green Supply Chain Initiatives Towards Environmental Sustainability. Operations And Supply Chain Management, 18(10), 1048-1050.

Eltayeb, T. K., \& Zailani, S. (2010). Investigation on the drivers of green purchasing towards environmental sustainability in the Malaysian manufacturing sector. International Journal of Procurement Management, 3(3), 316-337. https://doi.org/10.1504/IJPM.2010.033448

Gupta, S., Dangayach, G. S., Singh, A. K., \& Rao, P. N. (2015). Analytic Hierarchy Process (AHP) Model for Evaluating Sustainable Manufacturing Practices in Indian Electrical Panel Industries. Procedia - Social and Behavioral Sciences, 189, 208-216. https://doi.org/10.1016/j.sbspro.2015.03.216

Huang, Y. C., Yang, M. L., \& Wong, Y. J. (2016). Institutional pressures, resources commitment, and returns management. Supply Chain Management, 21(3), 398-416. https://doi.org/10.1108/SCM-04-2015-0144

Hami, N., Muhamad, M. R., \& Ebrahim, Z. (2016). The impact manufacturing sustainability of sustainable practices on sustainability. Jurnal Teknologi, 78(1), 139-152. https://doi.org/10.11113/jt.v78.3090

Hoffman, A. J. (2000). Competitive environmental strategy: a guide to the changing business landscape. In Choice Reviews Online (Vol. 38, Issue 02).

https://doi.org/10.5860/choice.38-1032

Iranmanesh, M., Zailani, S., Moeinzadeh, S., \& Nikbin, D. (2015). Effect of green innovation on job satisfaction of electronic and electrical manufacturers' employees through job intensity: personal innovativeness as moderator. Review of Managerial Science, 11(2), 299-313. https://doi.org/10.1007/s11846-015-0184-6

Jacobs, F. R., \& Chase, R. B. (2017). Process Design and Analysis. In Operations and Supply Chain Management (pp. 265-297).

Kamukama, N., Augustine, A., \& Joseph M., N. (2011). Competitive advantage: Mediator of intellectual capital and performance. Journal of Intellectual Capital, 12(1), 152-164. https://doi.org/10.1108/14691931111097953

Khor, K. S., \& Udin, Z. M. (2013). Reverse logistics in Malaysia: Investigating the effect of green product design and resource commitment. Resources, Conservation and Recycling, 81, 71-80. https://doi.org/10.1016/j.resconrec.2013.08.005

Lee, S. C., \& Na, S. I. (2010). E-waste recycling systems and sound circulative economies in East Asia: A comparative analysis of systems in Japan, South Korea, China and Taiwan. Sustainability, 2(6), 1632-1644. https://doi.org/10.3390/su2061632 
Mollenkopf, D. A., Frankel, R., \& Russo, I. (2011). Creating value through returns management: Exploring the marketing-operations interface. Journal of Operations Management, 29(5), 391-403. https://doi.org/10.1016/j.jom.2010.11.004

Madaan, J., Chan, F. T. S., \& Niu, B. (2015). Strategies for evaluating performance of flexibility in product recovery system. International Journal of Production Research, 54(10), 28952906. https://doi.org/10.1080/00207543.2015.1120899

Mitra, S., \& Datta, P. P. (2014). Adoption of green supply chain management practices and their impact on performance: An exploratory study of Indian manufacturing firms. International Journal of Production Research, 52(7), 2085-2107. https://doi.org/10.1080/00207543.2013.849014

Mitra, S. (2015). Models to explore remanufacturing as a competitive strategy under duopoly. Omega (United Kingdom), 59, 215-227. https://doi.org/10.1016/j.omega.2015.06.009

Menguc, B., \& Ozanne, L. K. (2005). Challenges of the "green imperative": A natural resourcebased approach to the environmental orientation-business performance relationship. Journal of Business Research, 58(4), 430-438.

https://doi.org/10.1016/j.jbusres.2003.09.002

Rao, P., \& Holt, D. (2005). Do green supply chains lead to competitiveness and economic performance? International Journal of Operations \& Production Management, 25(9), 898-916.

Ramakrishnan, P., Haron, H., \& Goh, Y.-N. (2015). Factors influencing green purchasing adoption for small and medium enterprises (smes) in malaysia. International Journal of Business and Society, 16(1), 39-56.

Rahman, S., \& Subramanian, N. (2012). Factors for implementing end-of-life computer recycling operations in reverse supply chains. International Journal of Production Economics, 140(1), 239-248. https://doi.org/10.1016/j.ijpe.2011.07.019

Shahbazpour, M., \& Seidel, R. (2006). Using sustainability for competitive advantage. 13th CIRP International Conference On Life Cycle Engineering, 287-292. https://researchspace.auckland.ac.nz/handle/2292/16700

Sekaran, U., \& Bougie, R. (2013). Research Methods for Business A Skill Building Approach, 6th Edition, Wiley, New York.

Shaharudin, M. R., Zailani, S., \& Tan, K. C. (2014). Barriers to product returns and recovery management in a developing country: Investigation using multiple methods. Journal of Cleaner Production, 96(2013), 220-232. https://doi.org/10.1016/j.jclepro.2013.12.071

Shaharudin, M. R., Zailani, S., Ismail, M., \& Mahdzar, S. F. A. (2016). A Descriptive Study of Malaysian Manufacturing Firms Experience in Managing Closed-Loop Supply Chain ( $\mathrm{p}$. 3245).

Shaharudin, M. R., Govindan, K., Zailani, S., Tan, K. C., \& Iranmanesh, M. (2017). Product return management: Linking product returns, closed-loop supply chain activities and the effectiveness of the reverse supply chains. Journal of Cleaner Production, 149, 11441156. https://doi.org/10.1016/j.jclepro.2017.02.133

Scur, G., \& Barbosa, M. E. (2017). Green supply chain management practices: Multiple case studies in the Brazilian home appliance industry. Journal of Cleaner Production, 141(September 2016), 1293-1302. https://doi.org/10.1016/j.jclepro.2016.09.158

Thatte, A. A., Rao, S. S., \& Ragu-Nathan, T. S. (2013). Impact Of SCM Practices Of A Firm On Supply Chain Responsiveness And Competitive Advantage Of A Firm. The Journal of Applied Business Research, 29(2), 1-294. 
Tan, C. L., Zailani, S. H. M., Tan, S. C., \& Yeo, S. F. (2019). Green supply chain management: impact on environmental performance and firm competitiveness. International Journal of Sustainable Strategic Management, 7(1/2), 91. https://doi.org/10.1504/ijssm.2019.10020498

Toffel, M. W., Stein, A., \& Lee, K. L. (2008). Extending Producer Responsibility: An Evaluation Framework for Product Take-Back Policies. SSRN Electronic Journal. https://doi.org/10.2139/ssrn.1262335

Thoo, A. C., Abdul Hamid, A. B., Rasli, A., \& Zhang, D. W. (2013). The Moderating Effect of Enviropreneurship on Green Supply Chain Management Practices and Sustainability Performance. Advanced Materials Research, 869-870, 773-776. https://doi.org/10.4028/www.scientific.net/amr.869-870.773

Um, J., \& Suh, S. H. (2015). Design method for developing a product recovery management system based on life cycle information. International Journal of Precision Engineering and Manufacturing - Green Technology, 2(2), 173-187. https://doi.org/10.1007/s40684015-0022-y

Ülkü, M. A., \& Hsuan, J. (2016). Towards sustainable consumption and production: Competitive pricing of modular products for green consumers. Journal of Cleaner Production, 142, 4230-4242. https://doi.org/10.1016/j.jclepro.2016.11.050

White, J. (2019). Competitive Advantage: Definition, Examples and Global Impact - TheStreet. 1-8. https://www.thestreet.com/personal-finance/education/what-is-competitiveadvantage-14869235

Wu, C. H. (2012). OEM product design in a price competition with remanufactured product. Omega (United Kingdom), 41(2), 287-298. https://doi.org/10.1016/j.omega.2012.04.004

Yan, M. R., Chien, K. M., \& Yang, T. N. (2016). Green component procurement collaboration for improving supply chain management in the high technology industries: A case study from the systems perspective. Sustainability (Switzerland), 8(2), 1-16. https://doi.org/10.3390/su8020105

Younis, H., Sundarakani, B., \& Vel, P. (2016). The impact of implementing green supply chain management practices on corporate performance. Competitiveness Review, 26(3), 216245. https://doi.org/10.1108/CR-04-2015-0024

Çankaya, Y. S., \& Sezen, B. (2018). Effects of green supply chain management practices on sustainability performance. Journal of Manufacturing Technology Management, 30(1), 98-121. https://doi.org/10.1108/JMTM-03-2018-0099

Zailani, S., Govindan, K., Iranmanesh, M., Shaharudin, M. R., \& Chong, s. Y. (2015). Green innovation adoption in automotive supply chain: The Malaysian case. Journal of Cleaner Production, 108, 1115-1122. https://doi.org/10.1016/j.jclepro.2015.06.039

Zailani, S., Govindan, K., Shaharudin, M. R., \& Kuan, E. E. L. (2017). Barriers to product return management in automotive manufacturing firms in Malaysia. Journal of Cleaner Production, 141, 22-40. https://doi.org/10.1016/j.jclepro.2016.08.160

Zailani, S., Jeyaraman, K., Vengadasan, G., \& Premkumar, R. (2012). Sustainable supply chain management (SSCM) in Malaysia: A survey. International Journal of Production Economics, 140(1), 330-340. https://doi.org/10.1016/j.ijpe.2012.02.008

Zailani, S., Shaharudin, M. R., \& Saw, B. (2015). Impact of kaizen on firm's competitive advantage in a Japanese owned company in Malaysia. International Journal of Productivity and Quality Management, 16(2), 183-210.

https://doi.org/10.1504/IJPQM.2015.071239 